\title{
Importance of Organization in the East Anatolian Animal Husbandry
}

\author{
Kadir Karakuşs,*, Turgut Aygün ${ }^{2}$, S.Seçkin Tuncer ${ }^{3}$, M. Fatih Çelen ${ }^{4}$, Siddik Keskin $^{5}$ \\ ${ }^{1}$ Department of Crop and Animal Production, Gevas Vocational School, Yuzuncu Y1l University, Turkey \\ ${ }^{2}$ Department of Animal Science, Agriculture Faculty, Yuzuncu Yil University, Turkey \\ ${ }^{3}$ Department of Crop and Animal Production, Ozalp Vocational School, Yuzuncu Y1l University, Turkey \\ ${ }^{4}$ Department of Animal Science, Agriculture Faculty, Uşak University, Turkey \\ ${ }^{5}$ Department of Biostatistics, Medical Faculty, Yuzuncu Y1l University, Turkey
}

Copyright $\bigcirc 2017$ by authors, all rights reserved. Authors agree that this article remains permanently open access under the terms of the Creative Commons Attribution License 4.0 International License

\begin{abstract}
Animal potential, suitable natural conditions for animal husbandry and in terms of population of animal breeders in Eastern Anatolia Region have an important place in our country. However, stocks supply, input costs of products are high. Manufacturers are inadequate in terms of quantity and quality of the product to obtain its products live in the issue price and the market, the forces of the lack of competition in the market, the purpose of the event, provided support and resources to benefit from the creation of reasons such as the expected rate of the organization and the organization can be said to be effective in adequately livestock sector in Eastern Anatolia Region. Organization of producers in the region to solve these problems effectively, to solve the problems of animal husbandry techniques, to obtain high quality products by increasing production, marketing, rising standards of living in reaching the level of social and economic well-being, in terms of agro-industrial integration and the creation of agricultural policy in the region will be a very important factor. Provided for this purpose in this study mentioned the importance of organization for the Eastern Anatolia and focused on solutions for the problems.
\end{abstract}

Keywords Eastern Anatolia Region, Animal Husbandry, Organization, Problem, Solution Proposal

\section{Introduction}

Agriculture, the sector plays a major role in the industrialization of the country. The largest share of this role played by the agricultural sector is producers' organizations. The manufacturer to act in an organized structure, from production to marketing, both for themselves and it is important for both countries. Organization is essential to achieve the objective of integration of agriculture and industry. As a result, product inputs, marketing structure, will have the opportunity to earn more income than the products they produce. In the European Union, about $50 \%$ of agro-based industries are carried out through these organizations. In Turkey, the organization honors by the manufacturer of the importance of knowledge as a result, today only $40 \%$ of the level of the organization. Livestock continues to be the current problems, lack of communication and cooperation between organizations, most of them are weak capital structure, such as some of the reasons to be away from the democratic structure the marketing of live animals and animal products, intermediaries play an important role due to the lack of association $[1,21,22$, 23].Turkey has an important potential in terms of agriculture, animal husbandry in Eastern Anatolia Region. In Turkey the most extensive meadows - pastures have, in terms of quality fodder for livestock production is a priority region $[.4,5,7$, 9, 10, 14, 15]. Eastern Anatolia Region, spread by the world known goat breeding increases the importance of the region [8]. Region, due to the geographical conditions of agriculture in mountainous areas are often made, long and hard winter months, the summer season is short, but rather a region where crop production is easy to harvest. Therefore, to make the region more farming, organic farming, and very suitable for the production of fodder crops. The area around the presence of cattle in Turkey, $24.4 \%$ of the reputation and the existence of small ruminants $34.3 \%$ has a reputation[2, 6] . A significant portion of the population of the region is the source of livelihood of farming, agro-industrial sector also has an important role in terms of providing input. Livestock in the region, mostly modern understanding of the technical and although there have been an important source of livelihood for the people. Livestock in the region of $65.4 \%$, with $19.2 \%$ of the companies over the cattle and the sheep are. Cattle up businesses in Elazığ, small businesses are known to be the province of Van $[5,6]$. Majority of the population engaged in animal husbandry in the region in 
order to meet the needs of the housework, while a very small portion of his determined for a commercial purpose [2].Livestock production in the region, is $79.11 \%$ of the total value of agricultural production, from $42.77 \%$, which is the value of this ratio is very high average in Turkey [6].

Lack of effective organizational model for the region as a priority breeding, breeding supplies, existing animal studies have been rather limited upward potential quality problems in the region is one of the priorities of livestock [14]. Grower to changing conditions and market coverage does not have a price. Medium-and long-term solution to the problems giving rise to these manufacturers for cooperatives, small businesses grow and needs to be integrated and dispersed. Compared to the rest of the region, Turkey is lower prices, producers are not effective in the determination of prices for a significant portion of, for example, the price of raw milk and dairy factories in determining the effectiveness of dairy attributed [11]. Created by traders in the market prices of wool and mohair [13].

Turkey Middle Eastern countries than previously with live sheep and lamb meat, sheep and goat marketing situation was a country [12]. While the deficit of the European Union in the products available in Turkey, failing to import the grounds of known animal disease [12, 24]. EU policies on how to apply for membership in the animal and determining the future for our country in the past, particularly in Middle Eastern countries such as sheep exports of livestock and livestock activities in the Eastern Anatolia Region in terms of the current location will be much more important. As a result, production and employment in this sector due to the economic and social life for the people of the region and an increase in the level of prosperity that will be provided.

Grower Associations businesses, members of the university, in collaboration with the public will be able to yield controls. In this way, enterprises, stud ram, goat, sheep and goats will have the opportunity to sell. Sheep and goat breeders associations of the current situation in the region in achieving the desired result with the exact meaning has been inadequate.

Common and widely dispersed rural settlement structure in the region, small producers failure to be effective in determining the product price and market conditions remain unable to withstand the manufacturer to sell their products at lower rates, but low enough to meet the costs of an organization requires strong reasons, such as to obtain [14]. Animal breeders organization, cooperatives, farmers associations, unions, foundations and associations are the main actors. However, these organizations can follow manufacturers' innovations in solidarity may not have a strong structure and protect their rights [19]. Organizations is new and could not reach a wider audience, due to the power of bargaining and price setting does not exist yet. And receive a very low percentage share of subsidies provided to the lack of organized structure is the main reason. There is enough to utilize loans and grants of breeders [5].

Existing organizations in livestock production in the Eastern Anatolia Region have not display effective and sufficient. Future actions must be more conscious and containing clear solutions for organizations in livestock.

\section{Solution Proposals}

\subsection{What should be done?}

- Making organizations in the region to ensure the protection of genetic resources, more qualified types and races can be obtained, provided the increase in production and employment $[14,16]$.

Location is not known to the people of a foreign animal studies on education and prevention, and projects on the basis of social security by providing support during migration, the obligation to take part actively in the project is important $[17,18]$

- Breeders' control and planning within the organizations they are members of the same should be done to reach the purpose of, and financial support $[14,15]$.

- The development of policies to support co-operatives operate in the required subjects.

- Organic farming subsidies to be provided.

\subsection{Marketing}

- Market policy, farmers increase their income and improve, maintain the balance of supply and demand, but also taking into account the organized producer and consumer satisfaction.

- $\quad$ Sheep and goat's milk in the price formation should take an active role in Sheep and Goat Breeders Association. Outside the breeding of sheep and goats by means of price support medium and long term to increase the production of milk and meat-type sheep farming enterprises specializing in growing conversion of state enterprises, cooperatives, processing and marketing of products in the form of businesses and organizations in the provision of inputs required.

- Meat, meat products and by-products of industrial marketing is the most appropriate organizational model of production to the consumer cooperatives and associations play an active role.

- $\quad$ Pricing should be based on carcass grading. For this purpose, livestock marketing co-operatives in the region expanded in sheep and lamb meat.

- Organizing for milk collection in the form of cooperatives or dairy operations should be supported as a first step.

- In the form of co-operative marketing policy should be considered in association with contract manufacturing.

- Sheep and goat meat for export subsidies should be carried out to increase the rate.

- Important broiler flora in the region, which is insufficient for the production of eggs and honey, and 
current developments in parallel with the more active organizations, especially in terms of production of organic poultry production, along with the creation of beekeeping activities required to support the organization.

- Producer Unions legislation should allow the market to make direct sales.

\subsection{Suggested Model}

- Breeding improved organizational model applied forces unique to the area should be identified and implemented urgently. Appropriate to the needs of the region with the members of the development and implementation of a breeding program is extremely necessary $[14,20]$.

- City of races rather than regional and national associations of local genetic resources is important for the establishment of unions.

- Breeding cattle breeders association milk yield records with a statement of breeders, but should be more modern methods.

- To watch the animals instead of numbering and tagging of identification may be modern.

- Breeding Sheep and Goat Breeders Association member companies overcome the problems identified and maintained dairy animals for the development of highly efficient breeding, breeding programs necessary planning, pre-pedigree and the pedigree record keeping, artificial insemination, shelter planning, provision of high-quality roughage profitability of enterprises the main influencing factors.

- Members of the excess supply of service and quality for breeding supply, breeding raising, or artificial Insemination Cooperatives established. With financial and technical support for this government, the public is important to ensure coordination with the university.

- From production to consumption, producer organizations at all levels must be enabled.

- To protect the rights of producers, to pass information to them, educate, place, and the necessity of the existence of organizations still important to make applications [19].

- In the structure of industry-related organization, care, feeding, health care and educational activities in the use of drugs is one of the animal scientist, employment of veterinarians and technical staff should be mandatory.

- Programs to be organized by unions, government agencies should be prepared in collaboration with the university.

- - Strengthening of producer organizations and management structures and legal arrangements related to autonomy is required.
- Area based subsidies should be determined according to the areas and topics.

- Development Agencies in order to increase the effectiveness of the Unions, Provincial Directorates of Agriculture and the University co-ordination is essential.

- Determination of the dimensions of commercial livestock enterprises and supports they need to be planned accordingly.

- Organizational important to be dealt with in all provinces in the region.

- Unity and processing co-operatives to sell their products through the creation of opportunities for animal breeders are required.

- The relevant units of the Ministry of Livestock breeders do support the manufacturer's obligation to be a member of the Union to take livestock support is important to increase the number of members.

- The first stage of the development of existing organizations approach would be more accurate than the establishment of new organizations. In this way, strengthening the capacity of organizations race improvement, the fight against animal diseases, animal feed issues organizations can produce more active services [3].

- Producer organizations will work together with the agro-industrialists studies should be done [9].

\section{Conclusions}

This is a priority in terms of the country's livestock is important to the economic and professional organization. In this context, the creation of policies in Turkey livestock, animal studies and in terms of production needs for the growing population of people working in the livestock sector in the region will be extremely important in raising the level of economic and social welfare.

\section{REFERENCES}

[1] Akman, N., Kumlu, S., 1998. Türkiye Hayvancılığının Örgütlenme Sorunları. 2. Zootekni Kongresi. 22-25 Eylül. Bursa. S: 34-52.

[2] Aksoy, A., Yavuz, F., 2008. Hayvancıllk İşletmelerinin Avrupa Birliğine Uyumu ve Rekabet Edebilirliği; Dogu Anadolu Örneği. Tarım Ekonomisi Dergisi, 14 (1): 37 - 45.

[3] Anonim, 2006. Dokuzuncu Kalkınma Planı 2007-2013. Hayvancılık Özel İhtisas Raporu. Ankara.

[4] Anonim, 20011a. Bingöl İli Hayvancılık Potansiyeli Profili T.C. Fırat Kalkınma Ajansı.

[5] Anonim, 20011b. Doğu Anadolu Bölgesi Büyükbaş Hayvancılık Çalıştay Raporu. T.C. Serhat Kalkınma Ajansı. 
[6] Anonim, 2012. Doğu Anadolu Kalkınma Ajansı Küçükbaş Hayvancılık Çalıştay Raporu.8-9 Haziran . Hakkari.

[7] Anonim, 2013a. http://www.volkanderinbay.net/tarimnet/hayvancilik.asp. Türkiye'de Hayvansal Üretim. (27 Nisan 2013).

[8] Anonim, 2013b. http://www.tusedad.org/incelemeayrinti.asp?Kod=31. Hayvanc1lık dünyaya Doğu Anadolu'dan yayıldı.6 Mayıs 2013

[9] Bakır, G., Söğüt, B., 1999. Van İli Sığırcılık Faaliyetleri ve Yetiştirici Birlikleri. Uluslar arası Hayvancılık Kongresi, 21-24 Eylül, İzmir.

[10] Daşcı, M., Çomaklı, B. 2006. Yaylacılık ve tarımsal açıdan önemi. Atatürk Üniv. Ziraat Fak. Derg. 37(2), 275-280.

[11] Demir, P., Sadi Aral, S., 2009. Kars İlinde Faaliyet Gösteren Süt Sı̆ğırcılık İşletmelerinin Karşılaştıkları Sorunlar ve Çözüm Önerileri. Vet Hekim Der Derg 80(3): 17-22.

[12] Ergül,M., 1994. Karma Yemler ve Karma Yem Teknolojisi. Ege Üniv.Zir.Fak.Yay.No: 384, İzmir, 280 s.

[13] Gürel, H.E., 1994. Özelleştirme. Yem Magazin, 8: 20-21.

[14] Karaca, O., Vanlı, Y., Kaymakçı, M., Altın, T., Kaygısız, A., 1993. Doğu Anadolu Bölgesinde Koyun Yetiştirmenin Sosyolojik Ekonomik ve Genetik Görünüşü. Yüzüncü Y1l Üniversitesi Ofset Matbaası. Van.

[15] Karaca, O., Aşkın, Y., Cemal, İ., Çivi, A., 1996. Doğu Anadolu Göreneksel Koyun Yetiştirme Sistemlerinin Çağdaş Islah Programları Bakımından Potansiyelleri. Hayvancılık Ulusal Kongresi, 18-20 Eylül, Ege Üniversitesi, Bornova, İzmir.
[16] Karakus, K, 2009.Gen Kaynağı Norduz Koyunu ve Keçisi. Türkiye Koyunculuk Kongresi. 12-13 Şubat, İzmir.

[17] Karakuş, K. 2011. Türkiye'nin canlı hayvan ve kırmızı et ithaline genel bir bakış. Iğdır Üniv. Fen Bilimleri Derg. 1(1): 75-79.

[18] Karakuş, K., Tuncer, S.S., Budağ, C, 2011. Van İli Çoban Eğitimi ve İstihdamı.7. Ulusal Zootekni Bilim Kongresi. 14-16 Eylül, Adana.

[19] Köroğlu, S., 2003. Avrupa Birliğinde ve Türkiye'de Tarımsal Örgütlenme. AT Uzmanlık Tezi.Ankara.

[20] Koyuncu E. , Pala A., Savas T., Konyalı A., Atasoglu C., 2006. Çanakkale Koyun ve Keçi Yetistiricileri Birligi Üyesi Keçicilik İsletmelerinde Teknik Sorunların Belirlenmesi. Hayvansal Üretim Derg. 47(1).

[21] Kumlu, S., 2000. Hayvancılık Örgütleri. Türkiye Damızlık Sığır Yetiștiricileri Merkez Birliği Yayınları. Yayın NO: 2. Ankara.

[22] Saçl1, Y., 2007. AB'ye Uyum Sürecinde Hayvancilık Sektörünün Dönüşüm İhtiyacı.Uzmanlık Tezi. Yayın No: DPT: 2707.

[23] Uysal, Y., Mazgit, İ., 1993. "Türkiye Hayvancılık Sektörünün Sorunlarının Çözümüne Yönelik Bütüncül Bir Yaklaşım”. Yaşar Eğitim ve Kültür Vakfi. S: 58. İzmir.

[24] Zincirlioğlu,M., 1997. Türkiye'de Karma Yem Üretimi ve Kullanımı. Yutav Uluslar arası Tavukçuluk Fuarı ve Konferans1'97. 14-17.. 